\title{
Fatal Hieroglyph: Mexico for Writers of Exile Malcolm Lowry and William Burroughs
}

\author{
María DeGuzmán*
}

In memory of my colleague Debbie López.

\begin{abstract}
Resumo
This essay explores the representation of Mexico in the work of British modernist writer of exile Malcolm Lowry and of U.S. Anglo-American post-war, postmodern writer of exile William Burroughs. Lowry's Under the Volcano (1947) and Burroughs's trilogy The Soft Machine (1961), The Ticket that Exploded (1962), and The Nova Express (1964) represent Mexico as a land of fatal hieroglyphs, as itself a fatal hieroglyph. Theoretically, a hieroglyph, as a condensation of space and time, is always already fatal _ "an anticipation of the end in the beginning" [Jean Baudrillard]. The fatal sign constitutes an attempted exorcism of conventional reality governed by the status quo. For Lowry and Burroughs, Mexico as place and text is the locus of the exorcism of demons, personal and cultural. In turning Mexico into a fatal hieroglyph of doom, both modernist and postmodernist writers draw on a long tradition of stereotyping primitivizations of Mexico. However, in the cases of Lowry and Burroughs, these stereotypical primitivizations also function as alternative modes of knowledge, symbol-making, and anti-narration, deliberate plumbings of the non-linear, irrational, and trans-temporal to deliver a backhanded blow against the European and Gringo colonizer / conqueror in Lowry's case and the malaise of Anglo-American military-industrial capitalism in Burroughs's.
\end{abstract}

Keywords: Malcolm Lowry. William S. Burroughs. Mexico. Hieroglyph. Exile.

* University of North Carolina at Chapel Hill. 
In her often-cited 1987 essay "La conciencia de la mestiza: Toward a New Consciousness," Chicana lesbian feminist writer and cultural critic Gloria Anzaldúa turned oracle sifts through the leaves and layers of Anglo culture and admonishes the Gringo, the North American, and specifically, I claim, the "American" of British descent, the Anglo ethnic: "Admit that Mexico is your double, that she exists in the shadow of this country [the United States], that we are irrevocably tied to her. Gringo, accept the doppelganger in your psyche" (ANZALDÚA, 1987, p. 86). My essay is not a study of influence (the influence of a British writer on a U.S. writer or vice versa), but, instead, of philosophical and cultural affinities, continuities and discontinuities centering around the use of Mexico in the work of British modernist writer of exile Malcolm Lowry and of U.S. Anglo-American post-war, postmodern writer of exile William S. Burroughs, the latter best known for his 1959 novel Naked Lunch. Both writers — each descended from a wealthy industrialist (Lowry's father was an English cotton broker and owner of cotton fields in Egypt, Peru, and Texas [SPENDER, 1965, p. xix-xx]; Burroughs's paternal grandfather, the commercially successful inventor of the precise mechanisms that made his adding machine possible [SKERL, 1985, p. 2]) - journeyed to Mexico toward the end of October, as el día de los muertos approached. Lowry went in 1936 and Burroughs in 1949, a mere two years after the publication of Lowry's famous novel set in Mexico titled Under the Volcano (1947), a work that inspired other U.S. writers such as Conrad Aiken, Allen Ginsberg, and Walt Curtis to follow in his footsteps and meet their "double" as Anzaldúa puts it, or as Curtis writes, their "shadow," "their lawless side," "escape valve" south of the border (CURTIS, 1997, p. 199). For both Lowry and Burroughs, Mexico, as shadowy double, was the site not only of cheap liquor, drugs, and sex, substances and experiences obtainable (at greater cost) in Britain and the United States, but also of el mundo al reves, the world upside down and blown to bits and pieces - "America" as hell rather than Eden or an Eden turned hellish, destiny as failure and death rather than as success and salvation, sexuality as homosexuality and prostitution rather than conventional heterosexuality and marriage, and civilization as ruin, Mayan and otherwise, "Atlantis" (LOWRY, 1965, p. 16) reduced to a mysterious and surreal rubble, to a Waste Land.

However, for both Lowry and Burroughs, Mexico represented more than the world-upside-down or the crumbling underbelly of (North) America. It signified personal and especially cultural catastrophe, disintegration (LOWRY, 1965, p. 136, 
55 ) or doom encoded in the hallucinatory tequila, mescal, and/or heroin-induced images of the Mexican landscape and its ruins, old and new. In short, Mexico itself was a fatal hieroglyph of the doom awaiting modern Western (particularly Northern European and "American") civilization and those controlled by what is presented in Lowry's 1947 Under the Volcano and Burroughs's 1960s trilogy The Soft Machine (1961), The Ticket that Exploded (1962), and Nova Express (1964) as its fascist or totalitarian capitalist logic of domination, military and economic. ${ }^{1}$

In some respects, Mexico was for these writers-turned-expatriate-exiles one more inexpensive, permissive (or perhaps differently regulated), and yet also punishing labyrinth of encounters South not merely of their respective countries, but their respective empires of origin, Britain and the United States. Lowry also traveled to and fictionalized the Philippines, Southeast China, Haiti, and Italy. Burroughs voyaged through Central and South America, lived in Tangiers, and fictionalized all these places along with Mexico. Both writers and their main protagonists and/or narrators - the Consul Geoffrey Firmin in Lowry's Under the Volcano and Bill / Johnny / Danny Deever / Clem Snide alternately oilman, redneck cowboy, public agent, and media man "working for the Yankee dollar" (BURROUGHS, 1980, p. 40) and carrying the virus of Yankee ideology in Burroughs's trilogy — simultaneously run away from and yet also act out neocolonial, imperial scripts of domination and subjugation, something like Herman Melville's character Redburn from his 1849 novel by that name.

The comparison to Redburn, rather than to the more obvious figure of domination, Captain Ahab from Melville's 1851 novel Moby Dick, is important because it helps to underscore the role that the protagonists and/or narrators occupy in an imperial military-industrial capitalist drama. They are not the captains of the ship of Empire, those at the helm running the show. Rather, they are in dubious service or, if one considers Lowry's ex-Consul Geoffrey Firmin (LOWRY, 1965, p. 222 - 223), even ex-service to the ship of Empire which they, William Blackstones "leaving the Puritans to dwell among the Indians" (LOWRY, 1965, p. 126), have abandoned. Lowry's narrative offers up a serious, tragic Redburn, resembling Melville's Pierre or Joseph Conrad's Lord Jim. Burroughs's narratives tender a comic Redburn or a Billy Budd “who must hang” (BURROUGHS, 1980, p. 165)

1 Important to remember is the fact that not all "capitalism" is the same and that history has demonstrated the emergence of various kinds of capitalism. However, a military-industrial capitalism, particularly in poorly regulated or unregulated hyper-capitalist form, tends toward totalitarianism. 
in a parodic register. The Hanged Man from the Tarot deck, a figure suspended upside down by one foot suggesting willing sacrifice of self or abdication of kingly power, furnishes the archetypal model for the main protagonist, tragic and/or comic, in Lowry's Under the Volcano and Burroughs's 1960s trilogy, particularly The Soft Machine.

Just as an archetype exists upon which the main characters are fashioned - that of the Hanged Man, Mexico plays a kind of Ur-role in relation to countries along and South of "the Tropic of Cancer" to borrow Henry Miller's famous title for his work, a mixture of fiction and memoir about the sexual adventures of a young expatriate writer, published in Paris in 1934 and banned for twenty-seven years in the United States. Of all the countries of the so-called "global south" mentioned in either Lowry's or Burroughs's work, Mexico occupies a central place as the appropriate location for the hanging, so to speak, of the Hanged Man. Besides in Under the Volcano and Burroughs's 1960s trilogy, Mexico appears as this kind of topos in numerous other works by the two writers. For instance, Mexico features in Lowry's collection of short stories Dark as the Grave Wherein My Friend is Laid (1968) and his Mexican poems The Lighthouse Invites the Storm. From Burroughs's 1952 Queer with its descriptions of Mexico in terms of its "pitiless... blue sky," "circling vultures," "blood and sand," "sheer filth and poverty," and "psychic and physical terrorism," (BURROUGHS, 1985, p. v-vii) to his 1987 The Western Lands, Mexico plays an important recurring role.

Mexico in Lowry's Under the Volcano and Burroughs's trilogy is not just any country "South" of "Northern" imperial nations, Britain and the United States. Lowry's novel and Burroughs's trilogy portray Mexico in terms of the founding of control-bent civilizations in the Western hemisphere - beginning with the pre-Columbian Aztecs and Mayans to the conquest and colonization of the Americas by Spain and other European powers, to more recent Anglo-American imperialization of the Americas. Hence, Under the Volcano describes murals by Diego Rivera, usually treated as the quintessential modern Mexican artist, as a pictographic condensation of these historical narratives:

The slow darkening of the murals as you look from right to left. It seems somehow to symbolize the gradual imposition of the Spaniards' conquering will upon the Indians. [...] If you stood at a greater distance still it might seem to symbolize for you the gradual imposition of the Americans' conquering friendship from left to right upon the Mexicans. (LOWRY, 1965, p. 212). 
Lowry's and Burroughs's own narratives are equally invested in the idea and the hieroglyphization of Mexico as "the seat of the history of" not only "the conquest," (LOWRY, 1965, p. 295) but of conquest itself.

The mural reference is part of an extended metaphor involving the concept of writing on the wall. Mexico as a mural is composed of successive layers of this pictographic script which both attests to and, often in Burroughs's fiction as well as Lowry's, constitutes a technique of conquest or of control as conquest through invasion and colonization. For example, gazing at a movie poster, M. Laruelle, one of the characters of Lowry's Under the Volcano, thinks to himself:

That poster looming above him now, showing the murderer Orlac! An artist with a murderer's hands; that was the ticket, the hieroglyphic of the times. For really it was Germany itself that, in the gruesome degradation of a bad cartoon, stood over him. (LOWRY, 1965, p. 25).

The passage suggests that the Mexican movie theater furnishes a "hieroglyphic of the times" - in this case, of Germany's attempted takeover of Europe in the 1930s and early 1940s. Furthermore, the prepositional phrases of the passage describing the movie theater poster - "looming above him" and "stood over him" — imply that this "ticket," this hieroglyph about conquest, also has the concresced power derived from an aesthetics of subliminal association to influence the thoughts, feelings, and destiny of the viewer.

"Hieroglyph," the literal meaning of which is "sacred inscription or carving," usually refers to a conventionalized picture of an object standing in for a world. As Burroughs points out in The Ticket that Exploded, like "word lines," it both embodies and depends for its effect on "controlled association" (BURROUGHS, 1987, p. 208). The sight of $X$ or $Y$ is supposed to trigger $X$ or $Y$ thought. To the extent that a hieroglyph symbolizes something that it does not directly figure, it may be said to contain a hidden meaning, for Lowry and Burroughs, generally of "sinister significance" (BURROUGHS, 1985, p. xviii). As an enigmatic symbol, it is readily available only to the initiated. Furthermore, as a series of enigmatic symbols, it constitutes a code, transparent to those who either have devised it or broken it. Presumably, the operators of the code can manipulate its signs and symbols for the purpose of colonizing and controlling others.

Lowry's Under the Volcano and Burroughs's 1960s trilogy depict Mexico as a culture founded on hieroglyphs. Lowry's novel concentrates on geological 
landmarks, two volcanoes, as hieroglyphs not only characterizing the landscape south of Mexico City, but, moreover, spelling a catastrophe that has branded Cuernavaca/Quauhnahuac with an indelible air of fatality — "wherever you turned the abyss was waiting for you round the corner" (LOWRY, 1965, p. 17). Burroughs's trilogy, on the other hand, treats a human-made textual monument, the Mayan calendar, as the key to Mexico:

I went to Mexico and studied the Mayans... The Mayans had a solar, a lunar, and a ceremonial calendar rolling along like interlocking wheels... The Mayan writings have not been fully deciphered, but we know that most of the hieroglyphs refer to dates in the calendar... the Mayan control system depends on the calendar and the codices which contain symbols representing all states of thought and feeling possible to human animals living under such limited circumstances - these are the instruments with which they rotate and control units of thought. (BURROUGHS, 1980, p. 91)

Lest one imagine that the hieroglyphs of the Mayan calendar pertain only to it and the Mayans who contrived it, the last novel of the trilogy, Nova Express, implies that this system has been disseminated all over Mexico and, in fact, composes the country: "Great winds whipping across a black plain scattered the codices and hieroglyphs to rubbish heaps of the earth — (A Mexican boy whistling Mambo, drops his pants by a mud wall and wipes his ass with a page from the Madrid codex)" (BURROUGHS, 1980, p. 225). Similarly, Under the Volcano intimates that Mexico is both founded on and composed of hieroglyphs of control. Examples of hieroglyphs that compose it or at least the Consul's and the reader's experience of Cuernavaca are the Ferris wheel which revolves "backwards" "in the dark tempestuous night," the pictures, posters, and signs in cantinas and movie theaters, "cuneiform stone idols," a murdered Indian lying along a road, and a ubiquitous sign in Spanish that reads, “¿Le gusta este jardín / que es suyo? / ¡Evite que sus hijos lo destruyan! [Do you like this garden / that is yours? / Keep your children from destroying it!] (LOWRY, 1965, p. 20, 199, 244). The sign in Spanish functions on various semiotic levels. It can be interpreted to reference an actual garden, but also Mexico and the greater New World as an "Eden" destroyed by conquest.

Ultimately, these works portray Mexico in toto as itself "a fatal hieroglyph of doom." Contrary to Stephen Spender's claim about Under the Volcano, that it "is not a statement about civilization so much as an account of one man's soul within 
the circumstances of a historic phase" (SPENDER, 1965, p. xii), the subject of doom in both Lowry's work and Burroughs's trilogy is not so much the individual psyches of the main protagonists or authorial personas as the cultures that they partly represent and normative discourse in general. Although the main characters may be alcoholics and junkies, none of these works, neither Lowry's and especially not Burroughs's, can be reduced to stories about individual addiction. Primarily, they are concerned with addiction in a wider and older sense of the word - meaning to give up one's control and, in Roman law, for instance, to be delivered, as if by judicial sentence, to a master (not oneself): in other words, to be a slave under a master's control, to be enslaved. These works plumb addiction as a historical, cultural, and philosophical problem of un-freedom rooted in the relation between and use of words and images. Addiction can be as much a nuclear arsenal and weaponry habit as a junk habit (BURROUGHS, 1987, p. 59). The need to be in control of others, whether through weapons or words and images or both in mutual reinforcement, can also be a form of addiction.

Lowry's and Burroughs's portrayals of Mexico do not simply fulfill the postRomantic artist's quest for a Luciferian world-upside-down, for a self-chosen hell or purgatory. Instead, their portrayals symptomize an investment in the pre-linguistic and the non-verbal, in that which, to borrow artist / visual theorist Victor Burgin's Roland Barthes-ian definition of the hieroglyph, "communicates instantaneously and stands outside discourse" (BURGIN, 1986, p. 119) or would seem to do so. In these works, Mexico is the land of signs that stand outside of normative discourse. Yet, as symbols in a semiotic system, they are analogous to that discourse. The analogical relationship between hieroglyphs doubles up for the doppelgänger effect between Mexico and Anglo-Euro-America.

Mexico's function as cultural doppelgänger for the "Anglo" writers' cultures (England and the United States) finds its condensed mimetic reflection in the juxtaposition of hieroglyph and word. The hieroglyph stands in as a double for the written word. However, while this double rivals linguistic discourse, it also marks a heightened awareness of discourse (oral, written, and pictured) as the code and encoding of civilization - and, as such, a means of social control like the Mayan calendar. In Under the Volcano and Burroughs's trilogy, Mexico as unfamiliar hieroglyph highlights the seemingly familiar Anglo-Euro-American culture as hiero-glyphed and as a culture whose codes are spelling waste, war, planetary devastation, extinction. Thus, in Mexico "the Consul wouldn't have 
needed a practiced eye to detect on this wall, or any other, a Mene-Tekel-Peres for the world, compared to which mere insanity was a drop in the bucket" (LOWRY, 1965, p. 146).

To say "fatal hieroglyph" is to purposely engage, for the sake of emphasis, in redundancy. Theoretically, a hieroglyph, as a condensation of space and time, is always already fatal. What is meant here by fatal? Jean Baudrillard provides a defining description of "fatal": "[T] he fatal is always an anticipation of the end in the beginning, a precession of the end whose effect is to topple the system of cause and effect" (BAUDRILLARD, 1988, p. 88). The fatal also topples conventional "reality" governed by the status quo and the "acceptable." The "power of the fatal sign" is that it is even more inexorable than that conventional reality (BAUDRILLARD, 1998, p. 100) and constitutes a kind of exorcism of it. Lowry's and Burroughs's works cast Mexico, place and hieroglyphic text, as the site for the exorcism of demons that may appear personal but are always cultural. One's culture, one's civilization, like alcohol or other kinds of drugs, can enslave one, too. In turning Mexico into a fatal hieroglyph of doom, both modernist and postmodernist writers draw on a long tradition of primitivizations of Mexico. However, what might be seen as fairly stereotypical capitulations to such primitivizations also function as alternative modes of knowledge, symbol-making, and anti-narration, deliberate plumbings of the seemingly non-linear, irrational, atemporal $^{2}$ (embracing past and future in a glance), to critique the European and Gringo colonizer / conqueror in Lowry's case, and the electro-chemical and media-controlled malaise of military-industrial Anglo-America in Burroughs's. In both cases, these representations of Mexico serve to cast serious doubt upon facile notions of linear, sequential history, progress, and space-time.

How and to what ends these texts exorcise these demons is best encapsulated in the image of the Ferris wheel in a Mexican amusement park in Lowry's Under the Volcano and in several scenes of Burroughs's trilogy. The Ferris wheel, designed by U.S. Anglo California Military Academy graduate and civil engineer George Washington Gale Ferris, Jr. (1859 - 1896) and inaugurated at the 1893 World's Columbian Exposition in Chicago, was a large upright wheel originally conceived to rival Paris's Eiffel Tower. It rotated on a permanent stand and had thirty-six cars (each fitted with forty revolving chairs) suspended from its rim

2 See Frances S. Connelly, The Sleep of Reason: Primitivism in Modern European Art and Aesthetics, 1725-1907 (University Park, PA: The Pennsylvania State University Press, 1995). 
as the wheel revolved. It could accommodate over two thousand passengers at any one time. During its years of operation (from 1893 to 1906) it carried over two-and-a-half million passengers. ${ }^{3}$ Since its invention, many other Ferris wheels have been built and operated in the United States and elsewhere around the world. Both Lowry's and Burroughs's text deploy references to a Ferris wheel as one of the most "fatal" of hieroglyphs in relation to its motion. Its rotating movement on a fixed axis, which ends where it began, suggests the inexorable prescripted and circular quality not only of history and culture but, moreover, of the normative discourse that underwrites them.

For Lowry and Burroughs, the Ferris wheel is perfectly analogous to the rigged machinery of discourse and ideology implicating anyone inserted into that discourse/ideology (or interpellated by it) in an endlessly self-replicating system. To express this idea another way, the Ferris wheel correlates to interpellation- to the mechanisms that spread the dominant ideology and bring subjects into being within its defining structures. For Lowry's Consul, the Ferris wheel is "the wheel of the law, rolling" (LOWRY, 1965, p. 218), and the law is as much discourse and ideology as existential fate. For Burroughs it is another avatar of the Mayan calendar that provides a "prewritten life script" (BURROUGHS, 1980, p. 154), an interconnected series of symbols that regulate thought through controlled association.

The question in both Lowry's and Burroughs's novels is how to break the rigged wheel of culture's words and images that keeps one addicted and enslaved to its control. Such a break signifies at least partial exorcism of historical and cultural demons of possession. Though Lowry's work is generally classified as modernist and Burroughs's as postmodernist, their texts attempt to exorcise these demons through similar means. They confound the rigged machinery of associations (that some might call "conventions") through montage, flashbacks, cut-up, abrupt changes of scene and perspective, and other devices that "mix everything up" like Burroughs's Puto the Cement Mixer, replacing orderly narrative movement with perpetual motion. Both Lowry's and Burroughs's text dare to literalize and even rival the Ferris wheel effect, fighting fire with fire or, in this case, the Wheel with wheels. This use of the master's tools to dismantle the master's house takes the form of repeating units of description and the duplication of endings in

3 For more information on the first Ferris wheel and the concept of Ferris wheels, please see Norman Anderson's book Ferris Wheels: An Illustrated History (Bowling Green, Ohio: Bowling Green State University Press, 1992). 
beginnings. These techniques draw the reader's attention to the very process of learned association. The texts suggest that consciousness of this process marks the start of a liberating detachment from the control of civilization's words and images.

Examining the work of Lowry, the British modernist, and that of Burroughs, the Anglo-American postmodernist, together substantiates elisions of British into Anglo-American culture as well as thematic and formal continuities between socalled "modernism" and "postmodernism." Such an examination also confirms some differences in the understanding of the fatality of the hieroglyph and its deployment as both narrative cause and textual effect. A clue to the most significant difference between Lowry's Under the Volcano and Burroughs's trilogy The Soft Machine, The Ticket that Exploded, and Nova Express can be discerned from the very titles of the works. Lowry's work, like so many modernist novels despite their claims to depart from the nineteenth-century novel, gives in to the pull of myths that mark definite beginnings and endings: the expulsion of Adam and Eve from the Garden of Eden, the sacrifice of the hero, or a version of apocalypse. Rather than breaking the Ferris wheel apart, the novel puts an end to its vertiginous movement by sacrificing the Consul to some fascistic Mexican police who throw his body into a ravine (reminiscent of a volcanic crater) along with that of a dead dog. Lowry's novel yields to the fatality of its own fatal hieroglyphs. It cannot resist closure because this kind of closure makes possible a certain tragic sublimity or declivity as the case may be. How else to end a story about an ex-Consul, an Englishman lost in Mexico, other than by martyrizing him under a volcano? Volcanic apocalypse taps into a particular kind of apocalypticism, geologically primitive, appealing to the penchant for grand myths rather typical of modernist quest texts.

Burroughs's novels, on the other hand, resist cathartic fatality by insisting on one significance of "fatal" over others - total exposure of means and ends rather than the mythic sacrifice of the hero. The "total exposure" of the workings of the rigged wheel instead of the stilling of its vertiginous movement is designed to break the wheel's logic of control over its subjects, including the reader. The titles of the novels, or rather anti-novels, in Burroughs's trilogy — The Soft Machine, The Ticket that Exploded, and Nova (as in the Spanish nova /does not go, work, function) Express - suggest, in typical postmodernist fashion, both aborted travel and proliferation: melting, exploding, ex-pressing. These are processes, more 
than actions. They differ from a modernist catharsis that nearly always involves intentional sacrifice, the death of the hero or heroine. Though Lowry's Under the Volcano and Burroughs's trilogy share the Hanged Man archetype, in the trilogy the Hanged Man is merely one more cipher of "Operation Total Exposure." This Operation functions as a kind of counter-apocalypse in which the Hanged Man turns into a trickster hierophant who, instead of submitting to control, re-programs the environment with his trickster tools. Burroughs's Nova Express urges readers to read the writing on the wall, the fatal hieroglyph of doom, learn the techniques of the Mayan calendar, and, like a hierophant turned trickster, do the following: "Call in the Chinese [and the Mayan and the Spanish] and any random factors. Cut all [reels of] tape. Shift cut tangle magpie voice [and word] lines of the earth... show you [and the boardroom "bastards"] 'Operation Total Exposure.' For all to see. In Times Square. In Piccadilly” (BURROUGHS, 1980, p. 197). The art to be practiced to defeat the social forces of control is one of revealing and defeating the logic of the dominant narratives by interrupting them with "random factors," cutting them up, folding them in, montaging, and scrambling their words and images.

Burroughs's experimented extensively with this kind of breaking and scrambling of "the verbal association lines" (BURROUGHS, 1989, p. 137) that erect walls or barriers around consciousness. But, his experimental writing also strives to imitate other media - film, and sound recording — as he wanted his verbal experiments to be as tactile and plastic a medium of communication as these other media in order to "produce certain effects on the human nervous system" (BURROUGHS, 1989, p. 28). These effects are designed to help liberate himself and others from the social conditioning / social control dictating their thoughts. The narrative logic of "word-locks" produced this social conditioning (BURROUGHS, 1989, p. 28, 49). Burroughs compares these word-locks or word-and-image-locks to the "most precise and hermetic control" calendar of the “ancient Mayans" (BURROUGHS, 1989, p. 38). The only way to break away from the control imposed by those in power (the Mayan priests then or the militaryindustrial order in post-World War II Anglo-American society) is to re-arrange, scramble, the elements of the calendar-like narratives and mainstream media of US society (including newspapers, television, and Hollywood film). Operation Total Exposure in Burroughs's Nova Express can be interpreted as the author's attempt to expose the ways in which a destructive, dominator civilization controls 
its citizens and gets them to be politically docile - through the use of fear and shame-mongering tactics and either/or binary "logic."

About nine years after the publication of Nova Express, in interviews from 1973 Burroughs calls these tactics "the tape recorders of Watergate" (BURROUGHS, 1989, p. 14). In these early 1970s interviews he describes a method for using the tape recorders of Watergate against regimes of control such as Nixon's. The method involves using several tape recorders (or whatever devices might furnish multi-tracks), recording opposing "realities," splicing or mixing together tracks that contradict each other and playing the mix back. Burroughs explains: "This cutting and playback can be very complex, involving speech scramblers and batteries of tape recorders but the basic principle is simply splicing sex tapes and disapproval tapes together" (BURROUGHS, 1989, p. 15). What is revealed is the absurd censorious logic of censorship and repression that depends on that which it opposes. The way to counteract this socio-political-and-psychological control is to expose its logic through recording, splicing, scrambling, and playback. Burroughs explores this prankster counteraction in his anti-novel novels that aim to expose what society's control tries to obfuscate - hence "Operation Total Exposure" for all to see "In Times Square. In Piccadilly," in the financial and cultural centers of US and British empire.

In his interviews as much as in his novels, Burroughs reminds readers of Mexico's Mayan culture as precursor and double of Anglo and Anglo-American cultures of control. In the interview "Journey through time-space" Burroughs's explains the importance of studying the Mayan calendar which he explicitly refers to as a "model system" of control:

The ancient Mayans possessed one of the most precise and hermetic control calendars ever used on this planet, a calendar that in effect controlled what the populace did thought and felt on any given day. A study of this model system throws light on modern methods of control. (BURROUGHS, 1989, p. 38).

By applying the phrase "model system" to the calendar of the Mayas of southern Mexico (as well as of Guatemala, etc.), Burroughs reverses EuroAmerican colonial and imperial assumptions about precedence, about which cultures are "models" and which imitators or copiers of what others have done. In his novels and interviews not only is Mexico the doppelgänger of the Gringo 
psyche, as Gloria Anzaldúa declares, but fatal hieroglyphic model for the empires of the United States and England implied in that phrase from the 1964 anti-novel Nova Express "In Times Square. In Piccadilly."

This critique of British and Anglo-American empire in Burroughs constitutes a continuity between his representations of Mexico and those of British modernist writer of exile Malcolm Lowry. Mexico for both writers is the place where they confront the Shadow, in the Jungian sense, of their own cultures - where they experience the hellish control-bent aspects of their own civilizations. At work here is a strong element of projection in the psychoanalytic sense. It is tempting to dismiss these representations as the hegemonic, colonial fantasies of white men "exiled" from their own cultures for various reasons. In many ways their representations do indeed serve as evidence for Anzaldúa's pointed observation about Mexico being the dopplegänger in the Gringo psyche, if by "Gringo" we can also include an Englishman such as Lowry. However, at the same time Lowry's and Burroughs's representations of Mexico are in themselves critiques, not so much of Mexico, as of their own cultures, of the problematic values of their own societies. Through an engagement with Mexico or certain aspects of Mexican culture, both writer exiles attempt an "exorcism" of their possession by their own cultures. Mexico is the place where demons are confronted and an imaginative attempted exorcism of them devised. Even in its negative manifestations, Mexico was vitally important to Lowry's and Burroughs's aesthetic and political visions rendered through the written word.

Malcolm Lowry (1909 - 1957) himself was already dead before Burroughs published The Soft Machine (1961), the first book in the trilogy. Under the Volcano was published in 1947, fourteen years before Burroughs's The Soft Machine and seventeen years before his Nova Express. However, Lowry's and Burroughs's novels advance critiques of Western imperialism, conquest, and capitalism with significant continuities between them. These critiques are not without their limitations. Indeed, they bear the traces of the colonialism they target. This is particularly the case in Lowry's Under the Volcano whose "incompletely decolonized" Consul, as environmental criticism and worldsystems postcolonial studies scholar Sharae Deckard argues, commands far too much attention and diverts it away from the sufferings as well as the agency of the Mexican characters (DECKARD, 2010, p. 51-76). Nevertheless, viewed as part of larger cultural patterns, Lowry's and Burroughs's written works (not necessarily 
their lives) symptomize the rise and spread of decolonial, liberationist expressions and movements from the late 1940s to the mid 1960s, as the publication dates of these novels indicate. Lowry's Under the Volcano can be seen as a pre-Beat work that inspired Beats such as Allen Ginsberg and Walt Curtis. Burroughs's novels or, more accurately, anti-novels are anti-authoritarian comic noir versions of Beat generation counter-cultural values in the post World War II era. Some of those key values were: rejection of materialism and mainstream, conventional narratives, the quest for spiritual and sexual liberation and exploration, experimentation with mind-altering drugs and/or Eastern religions or both, fomentation of youth movements and visionary utopianism as well as dystopianism connected with these, a keen interest in the convergence of verbal, musical, and visual arts, and a fascination with Mexico as a kind of antithetical mirror-image doppelgänger of the Gringo psyche (WATSON, 1998, entire book). Burroughs's trilogy embodies all of these values seen through the dark, smoked-glass-lenses of a deeply antiauthoritarian, critical paranoia that seems, unfortunately, merely lucidly realistic in the twenty-first century.

These Beat generation counter-cultural values are intimately connected with exile - whether that exile takes the form of actual expatriation from one's country or not. Beats both expatriated and, while in their own countries, lived in a state of flight and/or resistance from the hegemonic structures of control. In many cases, they were both expatriates and internal exiles. Mexico was a key destination in this double movement of expatriation and internal exile, certainly for many U.S. Beats, but also, apparently, for the proto-Beat English Lowry. Lowry's and Burroughs's representation of Mexico as fatal hieroglyph is the signature of their exilic consciousness. Lowry wrote Under the Volcano in a succession of places: Hollywood, Los Angeles; Cuernavaca and Oaxaca, Mexico; and Vancouver, Canada. He was far from his native New Brighton, Wirral (west coast of England), United Kingdom when he was working on his manuscript. Burroughs wrote most of his trilogy in London and Paris, far from his city of birth, St. Louis built in Missouri along the western bank of the Mississippi river on the border with southwestern Illinois. During his lifetime, Burroughs sojourned in many places: St Louis, MO; Cambridge, MA; Vienna, Austria; New York City; Texas; Mexico City; London; Paris; and Tangier in Morocco. Both Lowry and Burroughs were expatriates in the sense that they lived outside of their countries of birth for extended periods of time. However, Burroughs died in his native country, the 
United States. Lowry also died in his native country of England - in Sussex.

The terms "exile" relates to their lives and works in a less literalistic way than the term "expatriate." Neither writer was an "exile" if by "exile" one means a person forced to leave their country and barred from returning. Burroughs became an exile in this more literal sense of the word after he was arrested for forging drug prescriptions, drug possession, and drug distribution when he was living in New Orleans with his wife Joan Vollmer. To avoid conviction and serving time in Louisiana's Angola State Prison, he and Joan fled to Mexico. Then, when he "accidently" shot his wife in the head and killed her supposedly during a game of William Tell (or so the reiterated story goes), he fled Mexico and crossed back into the United States to avoid prosecution for culpable homicide. Mexican authorities tried him in absence and he was found guilty of culpable homicide and convicted to a two-year prison sentence which he never served because he had fled Mexico to which he was not returned by any US law enforcement (VALJAK, 2017, website). So, if he was an exile in the literal sense, he was one from the US for the period during which he lived with his wife in Mexico, having fled New Orleans to avoid going to prison. Not only was he an exile, but, furthermore, an outlaw, literally. However, the status of literal exile was temporary. Burroughs returned to the States and, although he lived in other places, he died in Lawrence, Kansas.

While not really "exiles" in the sense of being forced to leave and unable to return, Lowry and Burroughs were exiles according to another definition of the multivalent term "exile." They were "writers of exile" by which I mean that they wrote about exile (whether or not they were exiles in the more literal sense of the word). And, writing about exile entailed for them writing exile. This is no mere play on words. Writing "exile" is exactly what their texts do, each in its own way. Under the Volcano and the trilogy do describe exile, as should be evident from some of the passages I have quoted, but they do more than describe exile or furnish readers with characters who are exiles. The narratives (or, in Burroughs's case, anti-narratives) are written in such a way as to induce exile as a state of mind and being in their readers. Hence, the emphasis on ruination, loss, being cast out or rejected, wandering, catastrophe, fatality, and the attempted flight from or resistance to control. The novels, each in their own way, Lowry's in a tragic mode and Burroughs's in a comic noir mode, seek to alter consciousness, not merely represent it or talk about it. They seek to transmit exile as a state of mind, being, and action. This must be remembered in order to more fully understand what I 
mean when I claim that Lowry's and Burroughs's representation of Mexico as fatal hieroglyph is the signature of their exilic consciousness.

In their novels Lowry and Burroughs convert Mexico into the land of their own individual respective exiles. For example, Lowry made no secret of the fact that Under the Volcano was largely autobiographical. These writers, who themselves inspired other dissidents of various kinds to do the same, were following in a long tradition of both European and American and, more generally, global departures to Mexico (see GUNN, 1969). People had been going to Mexico for more than a century before Burroughs went in 1949 to escape punishment in the US. Many of those people who went to Mexico in the mid $19^{\text {th }}$ century were African-American fugitive slaves. In the late 1930s and early 1940s, Spanish Republicans during the Spanish Civil War fled Franco's forces by going to Mexico. And, during the Cold War in the United States, many US dissidents left for Mexico, as American Studies scholar Rebecca M. Schreiber discusses in her book (see SCHREIBER, 2008, entire book). But, Lowry and Burroughs, in turning Mexico into a fatal hieroglyph, break with the mimetic relation to actual exile in Mexico. Actual exile no longer determines the meanings or range of "exile."

Their works assign to Mexico, to aspects of its history, culture, and aesthetics, the eerie, alluring power of the fatal hieroglyph. While seeming to fall into an outrageous anti-Mexican stereotype, this representation of Mexico as fatal hieroglyph of doom is wielded against imperial, capitalist Western culture. Its deployment through the very words or hieroglyphs of the novels creates a textual environment for readers to inhabit. The fatal hieroglyph is not only produced through writing; it is the writing itself. It is a character, a semiotic sign, that scripts thought itself - that carries exile, like a virus, into the minds of readers to counteract the virus of hegemonic ideology presumed to already be lodged there. While this sounds rather ominous, this fatal hieroglyph might serve as an antidote to mind control, might begin to break the spell of dominant ideology or at least loosen its hold. By inhabiting this textual environment, readers can perceive through it, thus perceiving through an exilic consciousness themselves. This reading experience might be, potentially, deeply transforming. Exiles are less likely to feel at home within the dominant ideology. Instead, they feel displaced, alienated. They do not belong. This alienation and, more importantly, the recognition and acknowledgment of this alienation are, the texts suggest, precisely what is needed to germinate resistance to conquest and control. Of 
course, things are never this simple and one can find plenty of contradictions in the texts themselves and certainly within these authors' lives (though their lives are not the subject of this essay). To some extent, it would seem that their novels attempt to defeat one form of control with another. But, here one might appeal to the ways in which these kinds of texts, often jarring and disturbing and offering no panaceas or balms, might encourage reflection and critical thinking in their readers who might, in turn, produce their own forms of resistive agency.

\title{
Jeroglífico fatal: México para los escritores de exilio Malcolm Lowry y William Burroughs
}

\begin{abstract}
Resumen
Este ensayo explora la representación de México en la obra del escritor modernista británico de exilio Malcolm Lowry y del escritor estadounidense de postguerra y posmoderno William Burroughs. Under the Volcano (1947) de Lowry y la trilogía de Burroughs, The Soft Machine (1961), The Ticket that Exploded (1962) y The Nova Express (1964), representan a México como una tierra de jeroglíficos mortales, como si fuera un jeroglífico fatal. Teóricamente, un jeroglífico, como condensación del espacio y del tiempo, siempre es ya fatal: "una anticipación del fin en el principio" [Jean Baudrillard]. El signo fatal constituye un intento de exorcismo de la realidad convencional gobernada por el status quo. Para Lowry y Burroughs, México como sitio y texto es el lugar del exorcismo de los demonios, personales y culturales. Al convertir a México en un jeroglífico fatal de la fatalidad, tanto los escritores modernistas como los posmodernistas se basan en una larga tradición de estereotipos de primitivizaciones de México. Sin embargo, en los casos de Lowry y Burroughs, estas primitivizaciones estereotipadas también funcionan como modos alternativos de conocimiento, de creación de símbolos y de anti-narración, exploraciones deliberadas de lo nolineal, irracional y trans-temporal para dar un golpe contra el colonizador /conquistador europeo y gringo en el caso de Lowry y el malestar del capitalismo militar-industrial angloamericano en Burroughs.
\end{abstract}

Palabras-clave: Malcolm Lowry. William S. Burroughs. México. Jeroglífico. Exilio. 
References

ANDERSON, Norman. Ferris Wheels: An Illustrated History. Bowling Green, Ohio: Bowling Green State University Press, 1992.

ANZALDÚA, Gloria. Borderlands/La frontera: The New Mestiza. $1^{\text {st }}$ ed. San Francisco: Spinster/Aunt Lute Co., 1987.

BAUDRILLARD, Jean. The Ecstasy of Communication. New York: Semiotext(e), 1988.

BURGIN, Victor. The End of Art Theory: Criticism and Postmodernity. Atlantic Highlands, NJ: Humanities Press, International, Inc., 1986.

BURROUGHS, William. Interviews. In: ODIER, Daniel. The Job: Interviews With William S. Burroughs. New York: Penguin Books, 1989.

BURROUGHS, William. Queer. New York: Viking Penguin, Inc., 1985.

BURROUGHS, William. The Soft Machine. In: THREE Novels: The Soft Machine, Nova Express, and the Wild Boys. New York: Grove Press, 1980.

BURROUGHS, William. The Ticket that Exploded. 1962. Reprint. New York: Grove Press, 1987.

CONNELLY, Frances S. The Sleep of Reason: Primitivism in Modern European Art and Aesthetics, 1725-1907. University Park, PA: The Pennsylvania State University Press, 1995.

CURTIS, Walt. Mala Noche, \& Other "Illegal" Adventures. Portland: BridgeCity Books, 1997.

DECKARD, Sharae. "Perverse paradise": Malcolm Lowry and the writing of modern Mexico. In: DECKARD, Sharae. Paradise Discourse, Imperialism, and Globalization. New York: Routledge, 2010.

GUNN, Drewey Wayne. American and British Writers in Mexico, 1556-1973. Austin, TX: University of Texas Press, 1969.

LOWRY, Malcolm. Under The Volcano. 1947. Reprint. New York: J. B. Lippincott Company, 1965.

SCHREIBER, Rebecca M. Cold War Exiles in Mexico: U.S. Dissidents and the Culture of Critical Resistance. Minneapolis, MN: University of Minnesota Press, 2008. 
SKERL, Jennifer. William Burroughs. Boston, MA: Twayne Publishers, 1985.

SPENDER, Stephen. Intro. In: LOWRY, Malcolm. Under the volcano. 1947. Reprint. New York: J. B. Lippincott Company, 1965, pp. vii-xxvi.

VALJAK, Domagoj. Influential Writer William Burroughs accidently shot and killed his wife while demonstrating his "William Tell act." The Vintage News, 25 January 2017. Available at: < https://www.thevintagenews.com/2017/01/25/ influential-writer-william-burroughs-accidentally-shot-and-killed-his-wife-whiledemonstrating-his-william-tell-act/>. Last visited: 21 May 2017.

WATSON, Steven. The Birth of The Beat Generation: Visionaries, Rebels, and Hipsters, 1944-1960. New York: Pantheon, 1998. 